Journal of Jazz Studies vol. 10, no. 1, pp. 52-61 (Summer 2014)

\title{
Skin Deep: Race, Bias, and Fallacy in Terry Teachout's Ellington Biography
}

\author{
Stephen James with J. Walker James
}

Duke: A Life of Duke Ellington. By Terry Teachout. New York: Gotham Books. 2013. 483 pp.

I am Duke Ellington's nephew, the son of his only sibling Ruth. I grew up around my uncle and his orchestra, traveling with him in childhood and working with his band as an adult. Having a relative of historical significance requires a family to accept that their flesh and blood is part of the public domain. As Duke's reputation as a composer has grown, I have become accustomed to seeing him poked, prodded and dissected in scholarship and criticism. I have largely stayed out of the fray, trusting that Duke's body of work speaks to his genius much better than my words ever could. But the most recent book on Duke has caused me to make an exception. Duke: A Life of Duke Ellington, a widely acclaimed biography by Wall Street Journal drama critic Terry Teachout, should not be included into the library of jazz scholarship without serious scrutiny of its factuality, bias, and agenda.

The book, which attempts to diminish and qualify Duke's genius, has been lauded as a revelatory unmasking of Duke's life and psychology. But, while Duke is engaging, the tone is often pejorative and condescending. Factual flaws, some based on flimsy research, abound. Teachout frequently indulges in unfounded psychoanalysis that is so far removed from how Duke actually thought and functioned that it seems to shed more light on the book's author than its subject.

In past writings, Teachout confessed that he grappled with a period of racism as a young man in Kansas City before moving to New York City to become a writer. As a critic, Teachout has fixated on racial issues in jazz for nearly two decades, accusing prominent black jazz figures of reverse racism and arguing that white jazz musicians are not given enough credit and exposure. I have the utmost respect for all jazz musicians, regardless of their race. Duke also respected all musicians' contributions to jazz and saw art as beyond color and category. But Duke has served as a pawn in this ongoing debate, with Teachout stridently arguing that Duke has been overpraised by jazz's black

copyright by authors (c) Except where otherwise noted, this work is licensed under http://creativecommons.org/licenses/by-nc-nd/3.0 
intelligentsia. This biography appears to be an extension of Teachout's racially motivated jazz criticism.

Teachout begins Duke with these two sentences: "He was the most chronic of procrastinators, a man who never did today what he could put off until next month, or next year. He left letters unanswered, contracts unsigned, watches unworn and longtime companions unwed, and the only thing harder than getting him out of bed in the afternoon was getting him to finish writing a new piece of music in time for the premiere" (p. 1). Of all the aspects of Duke's life that he could have started with, Teachout willfully settles on the stereotype of a black man being late, lazy, and irresponsible. This opening salvo is attention grabbing but deeply misleading - a typically snide attempt by Teachout to unveil Duke's character. Duke produced over 2,000 pieces of music in his lifetime, hardly the output of a "chronic procrastinator." Duke slept late because he worked late, a common schedule for those in the entertainment business.

In the same prologue, Teachout labels Duke "an improbably gaudy bird of paradise." This derogatory reference to Duke's composition "Bird of Paradise," which was written for the Queen of England, paints Duke as a ridiculous animal while conjuring up the sort of exotic jungle imagery that Duke strove to rise above.

Teachout charges through sensitive racial issues continually, devoting the better part of a page to how Duke straightened his hair (p. 168). Teachout makes sure to mention that Malcolm X saw hair-straightening as "selfdegradation" and adds, "No amount of shame was too much to bear in the quest for good hair." Hair-straightening is a personal and often sensitive matter of choice. People of many ethnicities straighten their hair. I respect that as a biographer Teachout has to broach sensitive topics, but to claim that Duke's grooming choices were rooted in racial shame is not only presumptuous and offensive, but also dead wrong. Duke's hairstyle was a matter of personal preference. He liked the way it looked and enjoyed the black barbershop experience. Shame had nothing to do with it.

Teachout further indulges his racial fixation by portraying Duke as a sort of racist himself: a pampered, light-skinned snob who avoided contact with darker-skinned people. Teachout first sets Duke apart from the American black experience, groundlessly speculating that Duke did not "seem to have learned until later [in life] what less privileged black children know from the start of their young lives, which was that the color of their skin was enough in and of itself to get them killed, mutilated or thrown into jail" (pp. 30-31). I can assure you that both Duke and my mother, who were raised in the same household, were acutely aware of racial injustice from a very early age. They 
chose not to dwell on negatives, favoring a "rise above it" approach to racial indignities.

Teachout goes on to insinuate that Duke held himself above dark-skinned people. The author speculates that the lighter skin of Duke's known mistresses was "unlikely to be coincidental," and falsely insinuates that Duke preferred to associate with light-skinned members of the orchestra. Even the most cursory examination of Duke's life would show that the two men he was closest to in his organization were Billy Strayhorn and Harry Carney, neither of whom were light-skinned. Duke, who musically chronicled the black American experience in several of his works, was a champion of civil rights who spent his lifetime combating racism. He did not judge other human beings on the basis of skin tone. Terry Teachout is another story, as he confessed in his own memoir.

According to his 1991 memoir City Limits, ${ }^{1}$ Teachout saw black people as "shadowy," "romantic and unreal" until he began to encounter them frequently as a bank teller. Bitter at his lot in life, Teachout recounts sneering at his poor, black customers, believing they spent their government checks on "cards and whiskey and whores." He admits to shouting "nigger" out his car window into traffic as he drove through the streets of Kansas City.

His racism, he says, climaxed after a young black man was shot during an attempted robbery of the bank where he worked. As Teachout watched the man bleed to death, he wanted to "kick him in the head as hard as I could. I wanted him to die." He said to himself: "See this vile creature? They are all like that. He deserves to die." Then, Teachout resolves his vitriolic hatred of blacks in a twist that he calls "a fantastical coincidence, the kind of thing not even the most cynical screenwriter would dream of trying to palm off on a paying audience." Teachout's black co-worker comes sobbing from the teller line; the dying man is her cousin. In that moment, Teachout claims he is able to see black people as fully human. He concludes the chapter with the following words: "I cannot forget the malign impulse that once waited patiently inside me...I suppose it is still there, for no man can escape the shadow of his sinful nature...But that is something on which I prefer not to dwell, at least not for any longer than I can help."

Taken in isolation, Teachout's frank discussion of his years-long struggle with racism could be dismissed as a youthful transgression or even applauded for its honesty. But given the recurrent racial fixations that surface in his writings, Teachout's previous racial animus needs to be acknowledged and examined.

${ }^{1}$ City Limits: Memories of a Small-Town Boy (New York: Simon and Schuster, 1991). 
I am open to varying viewpoints about jazz as a whole and Duke in particular. But letting Teachout chronicle jazz history - even though he has tamped down his hatred - is like hiring a recovered alcoholic as night watchman at a vodka distillery. The proximity to temptation may become too great to resist. And, as the opening sentences illustrate, the readers of Duke do not have to wait long to see Teachout succumb to his old habits.

Teachout's campaign against Duke appears to have originated on the pages of Commentary, a neoconservative magazine that covers politics and the arts. In 1995, Teachout's essay "The Color of Jazz" leveled charges of reverse racism against several prominent black jazz figures. In 2008 he published "All That (White) Jazz," again asserting that white jazzmen have been historically marginalized. ${ }^{3}$

"The Color of Jazz" was written during a period of intense debate over affirmative action, which Teachout, a political conservative, opposed. In another essay from that time, "Ms. Wonder-Child, For Example," he argued against feminist revisionist theories of classical music, claiming that "women as a group may simply have a lower mean innate aptitude for large-scale musical composition than men."

In "The Color of Jazz," Teachout levels claims of reverse racism against the prominent critics Stanley Crouch and Albert Murray and accomplished trumpeter Wynton Marsalis, director of Jazz at Lincoln Center. For example, Teachout argues that Murray, in his book Stomping the Blues, focuses on the blues as the wellspring of jazz in order to reject the significance of white contributions. "Murray does not explicitly say that whites cannot play jazz," Teachout insists, "but that is what he means."

This pattern of projecting racism extends back to Teachout's memoir. At one point he assumes that a cashier at a Manhattan Burger King is a reverse racist based solely on how she looked "coolly at me as she took my order, not bothering to conceal the contempt in her eyes. I knew what she was thinking, for I had thought it, or at least something much like it, back in the days when I stared at poor black people and wished them dead." That the cashier was having a bad day, or that the look in her eye was something other than contempt, is not admissible for Teachout, who imposes racial filters and prejudices on the subjects of his writing time and time again.

\footnotetext{
${ }^{2}$ Commentary, September 1995, pp. 50-53.

${ }^{3}$ Commentary, November 2008.

${ }^{4}$ Commentary, March 1996, pp. 56-59.
} 
Within a year after "The Color of Jazz," Teachout published "(Over) praising Duke Ellington" in the same magazine. ${ }^{5}$ This time, the attack is by proxy. Teachout sets his sights on Duke Ellington, the professed musical hero of Crouch, Murray and Marsalis, and a linchpin of programming at Jazz at Lincoln Center. Teachout chips away at Duke's stature, claiming his composing talents have been overstated by Crouch, Murray and Marsalis in perpetration of a "racial myth" that is not "accessible to rational discussion." The rudiments of Duke are seen in this essay, which argues that Duke failed at composing extended works, stole ideas from his musicians, and has been wrongly classified as America's greatest composer. Teachout does not limit himself to taking Duke down a notch. He levels ad hominem attacks against Crouch and Murray, calling their musical assessments amateurish and attributing their worship of Ellington to insecurity. On Crouch and Murray favorably comparing Duke to white American composers, Teachout writes: "The oddly defensive belligerence of such extravagant comparisons tells us nothing useful about Ellington, but much about the degree to which even the most confident black intellectuals can be afflicted by self-doubt."

I do not wish to revive the divisive debates of yesteryear. Jazz is not a zero sum game. There is no need to diminish one man or group to build up another. But Teachout's earlier writings on these racial issues bear examination, since they contain in embryonic form the patterns and biases found in his new Ellington biography. Duke is derived almost entirely from previous works, then infused with Teachout's analysis and interpretation. The book contains no relevant new information and is riddled with inaccuracies and condescension. The arguments found in Commentary have gone from text to subtext. They are cloaked but palpable, more nuanced and less shrill. And Teachout's pattern of accusing black artists and intellectuals of ignorance and insecurity resurfaces.

In Duke, Teachout argues that Duke was incapable of composing without his orchestra; that he stole musically from his musicians; and that he was incapable of composing melodically memorable tunes. These three flawed arguments suggest either a willful unawareness or fundamental misunderstanding of both jazz and Duke Ellington. Duke kept a full orchestra on salary for touring, recording, and testing out new compositions. For Teachout this merely proves that Duke's orchestra was a crutch, and that he was incapable of composing without it. Duke certainly made full use of his orchestra's availability - and why shouldn't he? - but he was supremely capable of composing alone, as evidenced by the orchestration in his handwriting

${ }^{5}$ Commentary, September 1996. 
housed at the Smithsonian. Constant gigging was part of the band's business model, and performing nightly allowed Duke to engage in one of jazz's greatest defining factors: improvisation. Duke kept the band going because he was invigorated and inspired by it - not because he "had never acquired the conservatory-bred facility that would have allowed him to write out a piece of music in his studio, bring it to rehearsal and have his sidemen read it down note for note," as Teachout claims in one of his many impositions of a classical lens on the jazz genre.

The Cbicago Tribune's Howard Reich wrote that Teachout applies the "same rigid classical criteria" when panning Duke's longer-form works. Reich found these continual dismissals "tiresome: It indicates a narrow way of viewing a composer who always was pushing beyond category."

Teachout routinely shifts to whatever lens portrays Duke in an unflattering light. The allegation that Duke stole music is not new. But in a pre-publication interview for the blog JazzWax, Teachout boasts that he "is the first Ellington biographer to have noticed in detail the revealing fact that the most prominent and significant of his borrowings are usually found in his popular songs." Indeed, allegations of Duke stealing material center on popular songs. Did Teachout expect to find that disgruntled musicians would claim authorship of obscure, less profitable works? But the problem goes further: Teachout twists these obvious allegations into an assertion that Duke lacked the ability to compose the memorable melodic material needed for a popular tune.

Over the course of Duke's long career, there were a few claims by disgruntled sidemen that they "created" portions of Duke's popular songs. These claims are akin to tapping Vladmir Nabokov's shoulder, saying "Hey, why don't you write a book about a child molester?" and then trying to claim a double byline on Lolita. The melodic phrases and noodlings that coalesced into these songs were originally formed in conjunction with Duke, with the musicians playing off his suggestions and piano playing. Duke wove these melodic ideas into his compositions to feature his sidemen's strengths. The old allegation of song-stealing - and its twisted offspring that Duke was melodically deficient - further expose Teachout's inability to grasp how improvisation and collaboration function in jazz, as well as his rigid imposition of classical procedures on jazz.

\footnotetext{
${ }^{6}$ Chicago Tribune, November 10, 2013; http:/www.chicagotribune.com/features/books/ct-prj1110-duke-terry-teachout-20131110,0,628929. column?page $=1$

7 “Terry Teachout on Duke Ellington (Pt. 1)," Interview with Marc Myers, posted October 16, 2013; http://www.jazzwax.com/2013/10/terry-teachout-on-ellington-pt-1.html
} 
Just as Teachout accused Crouch and Murray of "musical ignorance," he writes pejoratively in Duke that Ellington was "ignorant of the rules of classical voice leading." Again, Teachout-an erstwhile part-time bassist in Kansas City-imposes classical criteria on a jazz musician without crediting him for forging his own methods and standards. Duke was aware of classical structures but chose not to follow a conventional path.

Teachout often paints Duke as more of a huckster or charlatan than an artist. At one point he writes, "When it came to high culture, Ellington was a poseur, a strangely incurious man who knew next to nothing about classical music and read not systematically but at random" (p. 198). A favorite and telling verbal tic of Teachout's is to reduce Duke's artistic successes to acts of magical prestidigitation or deceptive sleights of hand. The countermelody in Creole Love Call is "a card up his sleeve" (p. 66). Pondering how Duke would handle changes in post-WWII America, Teachout asks his readers: "What-if anything-did Harlem's Aristocrat of Jazz have up his sleeve?” (p. 256). An improvised musical portrait of First Lady Pat Nixon is "yet another of the onthe-spot musical miracles he had been shaking out of his sleeve for years" (p. 343). Duke's ballet collaboration with Alvin Ailey, The River, is "one more musical trick tucked up his now frayed sleeve" (p. 349).

In the final chapters, Teachout fixates on Duke's policy of playing his popular tunes at all of his concerts, saying that the cognoscenti despised the "dreaded medley." Teachout uses this phrase with gleeful scorn a gratuitous total of five times in the text of the book, as if there were something unseemly about Duke playing his hit songs for audiences, who flocked to concerts to hear Ellington standards.

Teachout wrote Duke at a seeming breakneck pace, debuting it ahead of the 2014 publication date he forecasted in a 2010 JazzTimes interview. From a factual standpoint, the work is riddled with errors and presumptuous psychoanalysis based on this false information. I cannot catalog all the errors here, but will detail a few based on my eyewitness account and supplementary fact-checking. In 1957, Edward R. Murrow's show Person-to-Person came to film Duke at the house where I lived with my mother on $106^{\text {th }}$ Street and Riverside Drive in Manhattan. Teachout, with no sourcing, claims the Murrow show was filmed at the apartment of Duke's long-time mistress Evie Ellis(p. 305). Evie never at any point resided at our Riverside Drive home. Teachout goes on to state that the use of Evie's apartment was "deceptive" and that Duke "kept Evie out of sight throughout the program," furthering his agenda of exposing Duke as a Lothario who treated women badly and shoved them into the background. 
Teachout keeps harping on this theme despite the fact that upon mentioning each of Duke's known paramours-his wife Edna and long-term mistresses Evie, Fernanda, and Mildred-he invariably remarks that little is known about the women. In addition to claiming that Evie was closeted away during the Murrow interview, he contends that Duke kept Mildred "out of sight." His evidence? She was not listed in the 1930 federal census. I wasn't born until much later and cannot state with certainty why Mildred was not on the census report-perhaps she was out for groceries when the census taker rang the doorbell. But I do know that Mildred was not hidden. She remained close to my family and my mother well into the 1960s. She was a documented employee of Duke's publishing company, and was photographed socially with my family. Had Teachout bothered to call me or any other living human being who knew Duke, he could have clarified Duke's treatment of women. Instead he chose to speculatively cast aspersions on Duke's character, even on topics he admits to knowing little about.

Perhaps the most dubiously sourced factual misrepresentation in Duke is the allegation that Duke knocked out the teeth of trombonist Lawrence Brown in 1970 when Duke was 71 years old (p. 346). Teachout's source was Duke's Bones, an obscure book on Duke's trombonists published in 1995. ${ }^{8}$ Duke's Bones does not source the story, saying it was "common knowledge" and claiming that Brown lost "several teeth." Teachout not only presents the allegation as accepted fact but also adds some imaginative flourishes, claiming that Duke knocked out Brown's two front teeth, and that Brown revealed this incident to no one "save close friends." I was working with the band at the time of this alleged incident. There is no way this could have occurred without word spreading. Brown was never silent when it came to his gripes about Duke. Nor was Duke given to violence, especially at that age. But even though the allegation is obviously flimsy and unsubstantiated, Teachout chooses to portray Duke as a violent gorilla who could not restrain himself from a fistfight at the age of 71 .

Duke's old age is where Teachout is at his most disparaging. In the final chapter of the biography, Teachout refers to Duke's appearance in old age as "seedy" and calls him a "seventy-year-old whose tank was nearly out of gas" (p. 346). He again casts aspersions on Duke's hair, calling his ponytail "grotesque," and takes a shot at Duke's haberdashery in the 1970s, saying he dressed in "gaudily 'mod' outfits, sometimes with embarrassing results.

\footnotetext{
${ }^{8}$ Kirt Dietrich, Duke's Bones: Ellington's Great Trombonists (Rottenburg, Germany: Advance Music, 1995).
} 
Teachout, who completed two years of undergraduate work in psychology, never hesitates to attribute Duke's actions to insecurity. Not only does Teachout suggest that Duke's hair choice was born out of a racial inferiority complex - he also says Duke's superstitions reduced him to a "quivering mass." $\mathrm{He}$ also insinuates that Duke was made to feel insecure by his protégé Billy Strayhorn. Duke was already a master composer when he met this unknown but brilliant young man, adopted him as a family member, and groomed him as a composer. Strayhorn was my godfather and an integral part of my family. His relationship with my uncle was in no way tinged by the jealousy and insecurity that Teachout suggests.

Perhaps the most telling reference to the inferiority complex Teachout has diagnosed in Duke and his black admirers is found in a recent interview with Darcy James Argue, in which Teachout taunts his detractors by attributing any criticism of his book to subconscious insecurity:

"Some Ellington buffs hate my book. I have ample reason to know that. And I think the reason why some of them hate it is because-whether they fully understand this or not-they don't believe that he's a great enough man to stand up to an honest discussion of what he was like, both as a man and as an artist."

I accept that my uncle, his music, and his legacy will be criticized and scrutinized. But I would hope that those who write about him do so with intellectual honesty and in the spirit of scholarship and better understanding. Unfortunately, Duke appears to be predicated on questionable bias and motivation, and its conclusions have been accepted for the most part without reservation or counterpoint in the media.

Duke has received plaudits from nearly all reviewers. It was a finalist for the National Book Award. In Kirkus Revierws it was one of the top ten nonfiction books of 2013. Most publications - including the New York Times ${ }^{10}$ - have blindly regurgitated the assertions and inaccuracies of Duke. A piece in The New Yorker ${ }^{11}$ used Teachout's negative portrayal as a springboard, reenvisioning Duke not as a composer, artist and master pianist but as a "dance band impresario who played no better than O.K. piano, got trapped for years

\footnotetext{
9 "Arranging Ellington: Interview with Terry Teachout," posted December 13, 2013; http://musicalexchange.carnegiehall.org/profiles/blogs/arranging-ellington-interview-withterry-teachout

${ }^{10}$ James Gavin, “Big Band: 'Duke: A Life of Duke Ellington,' by Terry Teachout, New York Times, December 6, 2013; http://www.nytimes.com/2013/12/08/books/review/duke-a-life-ofduke-ellington-by-terry-teachout.html?pagewanted=all\&_r=0

${ }^{11}$ Adam Gopnik, Two Bands: Duke Ellington, the Beatles, and the Mysteries of Modern Creativity, New Yorker, December 23, 2013, p. 121.
} 
playing 'jungle music' in gangster night clubs and at his height produced mostly tinny, brief recordings."

When I set out to write this piece, I disclosed my bias in the very first lines. Duke is my uncle, and it is only fair that readers know the position from which my knowledge and viewpoint emanate. Given the traction and acclaim Duke has achieved, Teachout's viewpoints and motivations must also be acknowledged and discussed. When Teachout put pen to paper at Duke's inception, he entered the project with a long-held belief that Duke had been overpraised and mythologized by black critics. His fixation on racial issues, combined with his own racist past, is suspect to say the least, and merits serious examination in light of his crusade to diminish the scope of Duke's genius. Thus far, the critic has gone un-criticized.

\section{About the Contributor}

StePHEn James is the son of Ruth Ellington, Duke Ellington's only sibling. $\mathrm{He}$ is the only living member of his generation of the Ellington family. As a child, he traveled with Duke and the band, sharing hotel rooms and transport with Duke. As an adult, he helped manage the band and administer the family's publishing business, Tempo Music. He contributed a chapter to the upcoming Cambridge Companion to Duke Ellington and lectured at the International Duke Ellington Study Group's 2014 conference in Amsterdam. $\mathrm{He}$ is currently working on a memoir of his time with his uncle.

The Journal of Jazz Studies (JJS) is published by the Institute of Jazz Studies at the Newark campus of Rutgers, The State University of New Jersey. JJS is hosted online by the Rutgers University Libraries at http://jjs.libraries.rutgers.edu. 